\title{
The Last Time Analysis of The Following Family in Al-Qur'an Perspective
}

\author{
R D Rahmah \\ Islamic Building School of Jagad Alimussirry Surabaya, Indonesia \\ Email: ronadwirahmah70@gmail.com
}

\begin{abstract}
Earthquakes are natural disasters caused by shocks on the earth due to faults and the sudden movement of tectonic rocks that make up the earth's crust. This study of earthquakes will be interesting if explored further from the perspective of the Qur'an because in the Qur'an there are many verses that speak of earthquakes. As explained in the Qur'an Al-Zalzalah verses 1-8. On February 142016 to February 23 2016 aftershocks occurred in the Klagon Village Area, Saradan District, Madiun. To analyze when the end of aftershocks ends by using the Least Square Method and the relationship of frequency of aftershocks to times that include the Omori, Omogi 1, Omogi 2 and Utsu methods. The conclusion of this study is the Omogi 2 method which has obtained the correlation coefficient $r=0.195$ from the correlation value $-1 \leq \mathrm{r}$ $\leq 1$, with the aftershocks ending on day 464 and from the comparison of aftershock frequency corresponding to the graph between the results data calculations with real data (actual data) namely the Omogi 2 method. And basically the term earthquake in the Qur'an can still be said not to make the verses interpreted as a single word containing the meaning of the earthquake as a brief explanation of aftershocks in the perspective of the Qur'an.
\end{abstract}

Keywords: Earthquake, Afterschocks, Omogi Method 2

\section{INTRODUCTION}

Since ancient times when the earth was in a circular shape that has not been known to humans until now, the earth's vast expanse of ocean and land has suffered from strange and unusual natural symptoms that are often referred to as natural disasters. Natural disasters are very diverse including one earthquake.

This study of earthquakes would be interesting if searched further from the point of view of the Qur'an because in the Qur'an there are numerous verses that speak of earthquakes.

As explained in the Qur'an the letter of $\mathrm{Al}$ Zalzalah verse 1. About an earthquake which means "When the earth is shaken with a shake (which is terrible").
The above verse is about one of the natural events called earthquakes. Through this verse, Allah Almighty explains that all mankind will be resurrected. Therefore, the day was named yaumul baas. Imam Ibn Katsir in his book of AlQur'an al-Adzim states that Ibn Abbas says "When the earth is shaken," it is moving from beneath it. "And the earth did lift its burdens," But this one catastrophe involved many human roles as stated in the Ar-verse verse 41 which means "There has been damage done to land and to the sea by human hands; Allah wants them to feel some of the consequences of their actions, that they may return (to the right path). "

On February 14, 2016 to February 23, 2016 an earthquake occurred in the Klagon Village Area, Saradan District, Madiun. This earthquake occurred repeatedly which is commonly called 
aftershock to find out when the earthquake will end, so this research was conducted. by analyzing the time that aftershocks end.

Based on the conditions above, this paper seeks to estimate when the aftershocks will end using the Omori, Omogi 1, Omogi 2 and Utsu methods and compares the results of aftershock calculations with aftershock frequency graphs. In addition to describing the phenomenon of earthquakes in perspective in the Qur'an.

\section{METHOD}

This study uses data used from the Meteorology Climatology and Geophysics Agency (BMKG) in the form of aftershocks, Klangon earthquakes on February 142016 February 232016 , or about 10 days with locations of $-7.03^{\circ}-7.88^{\circ} \mathrm{LS}$ and $111.44^{\circ}-111.62^{\circ} \mathrm{BT}$

\section{RESULT AND DISCUSSION}

Table 1. Correlation coefficients (r) and time for each method

\begin{tabular}{|c|c|c|}
\hline Method & $\mathbf{r}$ & $\mathbf{t}$ (day) \\
\hline OMORI & 0,30855 & 214 \\
\hline OMOGI 1 & $-0,0172$ & 4000 \\
\hline OMOGI 2 & $-0,1951$ & 464 \\
\hline UTSU & $-0,0177$ & 89 \\
\hline
\end{tabular}

Based on calculations that have been done using the Omori method, the correlation coefficient value $r=0.308$ estimated that the aftershocks ended on the 214th day from these results, it can be seen that the correlation coefficient value of the Omori method is less than 1 or -1 , this causes this method less show the suitability of the calculation. Thus, the Omori method is not suitable for estimating or predicting the end of aftershocks in the Klagon Village Area, Saradan District, Madiun.

From the four methods used it can be seen that the Omogi 2 method which is only close to 1 or -1 shows that the Omogi 2 method is more suitable for estimating or predicting the end of aftershocks.

Figure 1. Comparison Graph of Frequency of Aftershocks

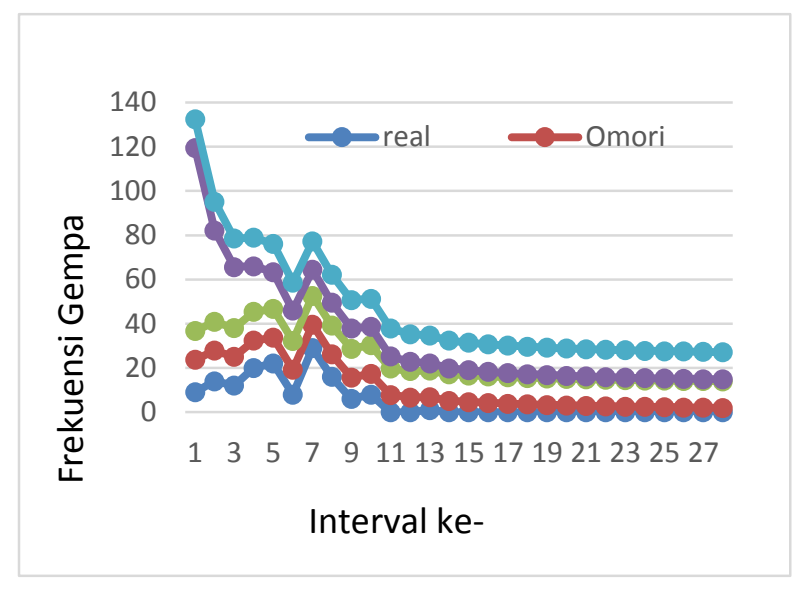

The picture above is a comparison of the frequency of aftershocks in Klagon Village, Saradan District, Madiun against the time for the Omori, Omogi 1, Omogi 2 and Utsu methods. From the picture above it can be seen that in accordance with the calculation data with real data (actual data), namely the Omogi 2 method. Because the end of the aftershocks in the Omogi 2 method occurred on the ninety-fifth day. These results approach the actual data of the end of the aftershock that occurred on the ninety-seventh day.

In the perspective of the Qur'an found 4 verses that tell directly about the phenomenon of earthquakes which are also followed by the cause and effect of the earthquake, 3 verses are found in Surah Al-a'raf verse 78, then Surah Al-'Ankabuut verse 37 , Surah Al-Waqi'ah verse 4, then Al-Fajr verse 21 .

\section{CONCLUSION}

The conclusion obtained from the calculation of aftershock decay (aftershock) for the Klagon Village Area, Saradan District, 
Madiun can be concluded that the appropriate method and approaching the reality in the field to estimate the end of aftershocks is the Omogi 2 method which has obtained the correlation coefficient $r=0.195$ of the correlation value $-1 \leq$ $r \leq 1$, with the aftershock ending on day 464 . Comparison of the frequency of aftershocks according to the graph between the calculated data and real data (actual data), namely the Omogi 2 method. These results approach the actual data of the end of the aftershock that occurred on the ninety-seventh day. And basically the term earthquake in the Qur'an can still be said not to make the verses that are interpreted as a single word and meaning an earthquake, it's just that there is a similarity and similarity in nature or the results obtained, as in an explanation of the verses containing the meaning of the earthquake as a brief explanation of the aftershocks in the perspective of the Qur'an.

\section{REFERENCES}

[1] Awaludin, Adang. 2010. Penentuan Waktu Berakhirnya Gempa Susulan untuk Gempa Bumi
Biak 16 Juni 2010. Jakarta: Skrispsi S1 UIN Syarif Hidayatullah.

[2] Efendi, Rahmat. 2011. Analisis Waktu Berakhirnya Gempa Bumi Susulan dengan Metode Mogi. Jakarta: Skripsi S1 UIN Syarif Hidayatullah

[3] Gofar, Mohammad. 2008. Gempa Bumi dalam Perspektif Al-Qur'an. Yogyakarta: S1 UIN Sunan Kalijaga

[4] Hariyono, Eko. 2016. Pengantar Geosains Fokus Kajian Gunung Api. Surabaya: Unesa University Press

[5] Putri, Ekarama, dkk. 2016. Analisis Karakteristik Prakiraan Berakhirnya Gempa Susulan pada Segmen Aceh dan Segmen Sianok. Sumatera Barat: Jurnal Fisika Unand Vol. 5.

[6] Zamri, Ahmad M. B. M. 2013. Relevasi Sains dengan Makna Zalzalah dalam Al-Qur'an (Kajian Tafsir Teamatik). Riau: Skripsi S1 UIN Sultan Syarif Kas. 